\title{
The Late Neoproterozoïc Continental Tholeiitic Basalts of the Toubkal Inlier (Western High-Atlas, Morocco): A Post-Pan-African Rifting Witness in the Northern Margin of the West African Craton
}

\author{
Ghalem Zahour ${ }^{1}$, Hassan El Hadi' ${ }^{1}$, Abdelfatah Tahiri ${ }^{2}$, Youssef Zerhouni ${ }^{1}$, Saida Alikouss ${ }^{1}$, \\ Rachid Zahour ${ }^{1}$, Aicha Reddad ${ }^{3}$ \\ ${ }^{1}$ Laboratory of Paleobelts Geodynamic, Sciences Faculty of Ben M'sik, Hassan II University of Casablanca, \\ Casablanca, Morocco \\ ${ }^{2}$ Geology and Remote Sensing Laboratory, URAC46, Mohammed V University of Rabat, Scientific Institute, \\ Rabat, Morocco \\ ${ }^{3}$ Laboratory of Géosciences, Science and Techniques Faculty, Guéliz, Cadi Ayyad University, Marrakech, \\ Morocco \\ Email: elhadihas@gmail.com
}

Received 28 May 2016; accepted 18 July 2016; published 21 July 2016

Copyright (C) 2016 by authors and Scientific Research Publishing Inc.

This work is licensed under the Creative Commons Attribution International License (CC BY).

http://creativecommons.org/licenses/by/4.0/

(c) (i) Open Access

\section{Abstract}

The late Neoproterozoïc Toubkal inlier (Ancient Massif of the High-Atlas, Morocco) contains two igneous basaltic series (Tircht and Sidi Chamharouch). Investigated rocks display characteristics of within-plate continental tholeiitic and are similar to rocks originated in orogenic contexts. The geochemical results allow the assumption that subduction active processes are indirectly responsible for the genesis of theses rocks. The orogenic signature is linked probably to a Pan-African magmatic source previously metasomatized in the northern margin of the West African Craton.

\section{Keywords}

Toubkal Inlier, Late Neoproterozoïc, Continental Tholeiites, Rift, West African Craton 


\section{Introduction}

The Late Neoproterozoic volcanism of the Western High Atlas, Morocco (WHA) (Figure 1), mainly represented by volcanic rocks with andesitic to dacitic composition (e.g. [1]-[3]), is located to the north of the Tizi n’Test Fault [4]. It was assigned to be Late Neoproterozoic to Early Cambrian in age [5].

Recent investigations in the eastern and western part of the WHA concern particularly the Late Neoproterozoic basalts of the Toubkal inlier (Figure 1). The aim of this paper is to present new geochemical data concerning this volcanism, to constrain its tectonic setting and to discuss its attachment for the late Pan-African history (rifting) of the West African Craton northern margin [3] [5]-[7].

The investigated basaltic rocks crop out in two areas (Figure 1): respectively in the eastern (Tircht series) and the western (the Sidi Chamharouch series) parts of the WHA.

In spite of alteration processes, which primarily affect some of the major elements, the original textures and minerals are usually preserved. Basaltic rocks display evidence of calcitization, sericitization, chloritization and silicification. New six major and trace (including rare earth element) analyses make it possible to characterize the magmatic affinity, nature and origin of the Toubkal inlier basaltic rocks. Chemical analysis of the studied rocks was carried out in the CRPG, Nancy (France). The major elements were performed by ICP-AES and the trace elements by ICP-MS.

As the basaltic rocks of the Toubkal inlier have undergone some effect of hydrothermal alteration, our interpretation is focused primarily on the high field strength elements (as $\mathrm{Nb}$, $\mathrm{Ta}, \mathrm{Zr}, \mathrm{Hf}$ ) and the rare-earth elements which are generally considered as immobile during alteration [8].

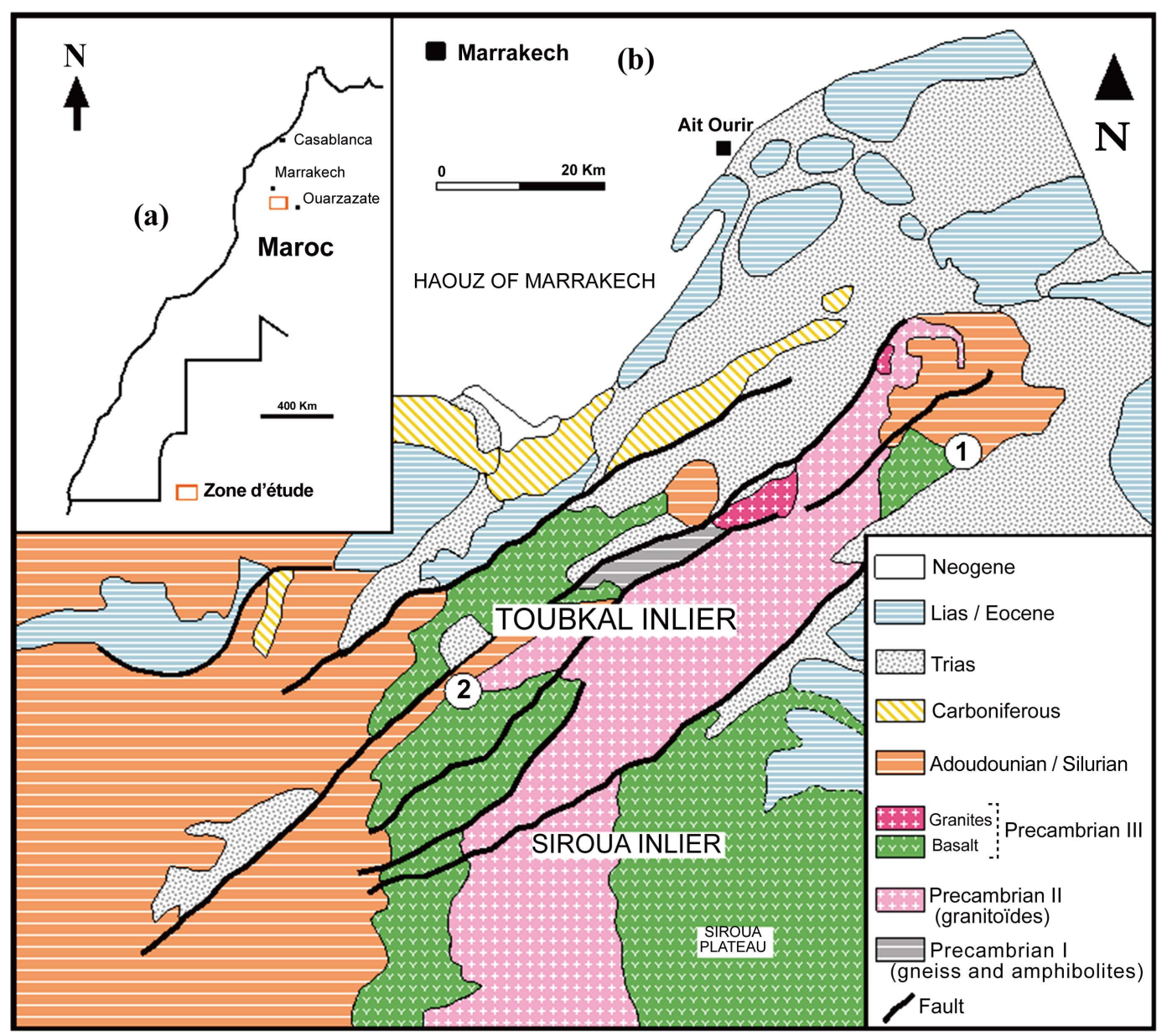

Figure 1. (a) Location of the Toubkal inlier in the map of Morocco, (b) Geological sketch map of the Toubkal inlier in the High Atlas Old Massif (after Proust, 1973 modified). 1: Tircht sector; 2: Sidi Chamharouch sector. 


\section{Geological Setting}

The Toubkal inlier is a domain oriented ENE-WSW which is limited to the south by the south-atlasic fault (Figure 1). In the north, it is bounded respectively from the west to the east by the Imlil, Ourika and Meltsene faults. These accidents representing branches of Tizi-N-Test fault [4] have an average direction of 70 to 80 .

In the Toubkal inlier, the studied volcanic formations belong to a vast old material which is known as "the Eastern Block of the Western High-Atlas massif” or “Headland of Ouzellarh” [9]. It is constituted by: (i) Paleoproterozoic (Ourika valley Precambrian I; Choubert and Faure-Muret, 1973), which consist of gneiss and amphibolites highly metamorphosed by the Eburnian orogeny [10]; (ii) Neoproterozoic (Upper Precambrian II and Precambrian III ([5] [11]) represented by granodiorites, dacites [12] and lavas of varied composition (basalts, andesites, rhyodacitic ignimbrites, rhyolitic ignimbrites) associated with “volcanoclastites” [12]. The matters are observed in the West (Sidi Chamharouch sector) and in the East (Tircht sector). In the Tircht locality, datations (U/Pb on zircon) gave an age of $585 \pm 15$ Ma for the rhyolites, and $563 \pm 20$ Ma for the Meltsene pink granite. Dolerite dykes [12] which transect the Sidi Chamharouch rocks are attributed to the Precambrian III (Late Neoproterozoic or Ediacaran).

\section{Lithostratigraphy}

The Tircht basic lava (Upper volcanic cycle, Figure 2(a)) overcome a thick Lower volcanic cycle (500 m) containing fragments of rocks originated from the immediate substratum which consists of calc-alkaline rhyodacitic ignimbrites (100 m) [12] and pyroclastites (40 to $150 \mathrm{~m}$ ) and ended by epiclastic rocks. The Upper volcanic cycle $(500 \mathrm{~m})$ starts with a decametric basalt flow $(10$ to $20 \mathrm{~m}$ ) of purple colour with fine white feldspar crystals and a second vesicular flow $(90 \mathrm{~m}$ ) of greenish grey colour. The vesicles which may reach $2.5 \mathrm{~cm}$ in diameter are of round or elliptic shape.

Basalts, which are the subject of this study, are covered by rhyolitic ignimbrites $(860 \mathrm{~m})$ of alkaline affinity [12] [13]. These rhyolites gave an age of $585 \pm 15 \mathrm{Ma}$, which postdates the late Pan-African orogenic phase $\left(\mathrm{B}_{2}\right)$ dated to $623 \pm 18 \mathrm{Ma}$ [14]. The calc-alkaline rhyodacitic ignimbrites form a shape-dome extrusion. The basalts and ignimbrites from the Upper cycle are organised in a type-stratiform volcano. However, the settlement of the volcanism of Tircht will be controlled by volcano-tectonic activity inherited from the lower Proterozoic and corresponds probably to the old south-atlasic fault activity. These tectonic lineaments are (actually) oriented W-E to WNW-ESE and functioned in the Precambrian III as normal faults associated to an NS extension. Later, the volcanic formations of Tircht were raised by these faults (re-activity) during the atlasic orogeny before they are eroded.

The basic lava succession of Sidi Chamharouch, 950 m (Figure 2(b)) consist of (i) an upper Precambrian II volcanic unit (dacite, quarzitic diorite) and (ii) a Precambrian III volcanic unit (rhyolites, andesites, ignimbrites, and megaphyric or doleritic basalts) of a post-orogenic calc-alkaline affinity [12]. The last volcanic unit, which contains the studied basalts, is unconformably overlain by cambrian schists.

\section{Petrography}

\section{(i) Basalts of Sidi Chamharouch}

According to macroscopic and microscopic aspects and to the mineralogical compositions, two main facies are distinguished (Figure 2(b)):

Pyroxene-bearing doleritic basalts: The primary paragenesis of these rocks is made of plagioclase (40\%; 0.1 mm - $1.5 \mathrm{~cm}$ ), augite (25\%; 0.1 - $0.5 \mathrm{~mm})$, opaque and olivine (13\%; 0.5 - $4 \mathrm{~mm}$ ) completely chloritized and opacified. The mesostase (20\%) contains microlitic plagioclase. Locally, these microlites are included partly or entirely in augite conferring to the rock a subophitic texture. More rarely, pyroxene can fill the open space between plagioclase (intersertal texture). The mesostase displays vesicles with sequential filling made of calcite in the walls and chlorite in the core. The rock is locally affected by microfractures which are filled by calcite.

Megaporphyric basalts: Primary mineralogy (30\% - 50\%) of this facies consists of plagioclase (30\% - 45\%; $0.1 \mathrm{~mm}-3 \mathrm{~cm}$ ), opaque (1\% - 5\%; 0.05 - $0.5 \mathrm{~mm})$ and olivine (1\%; 0.25 - $1.75 \mathrm{~mm}$ ) completely opacified. The mesostase $(50 \%-70 \%)$, sometimes vesicular contains microlites of plagioclase in a partially or completely opacified matrix. It includes millimetric to centimetric vesicles, filled by calcite, chlorite, quartz (monomineral or sequential). In this last case, quartz occupies the walls and calcite the core of the vacuoles. 


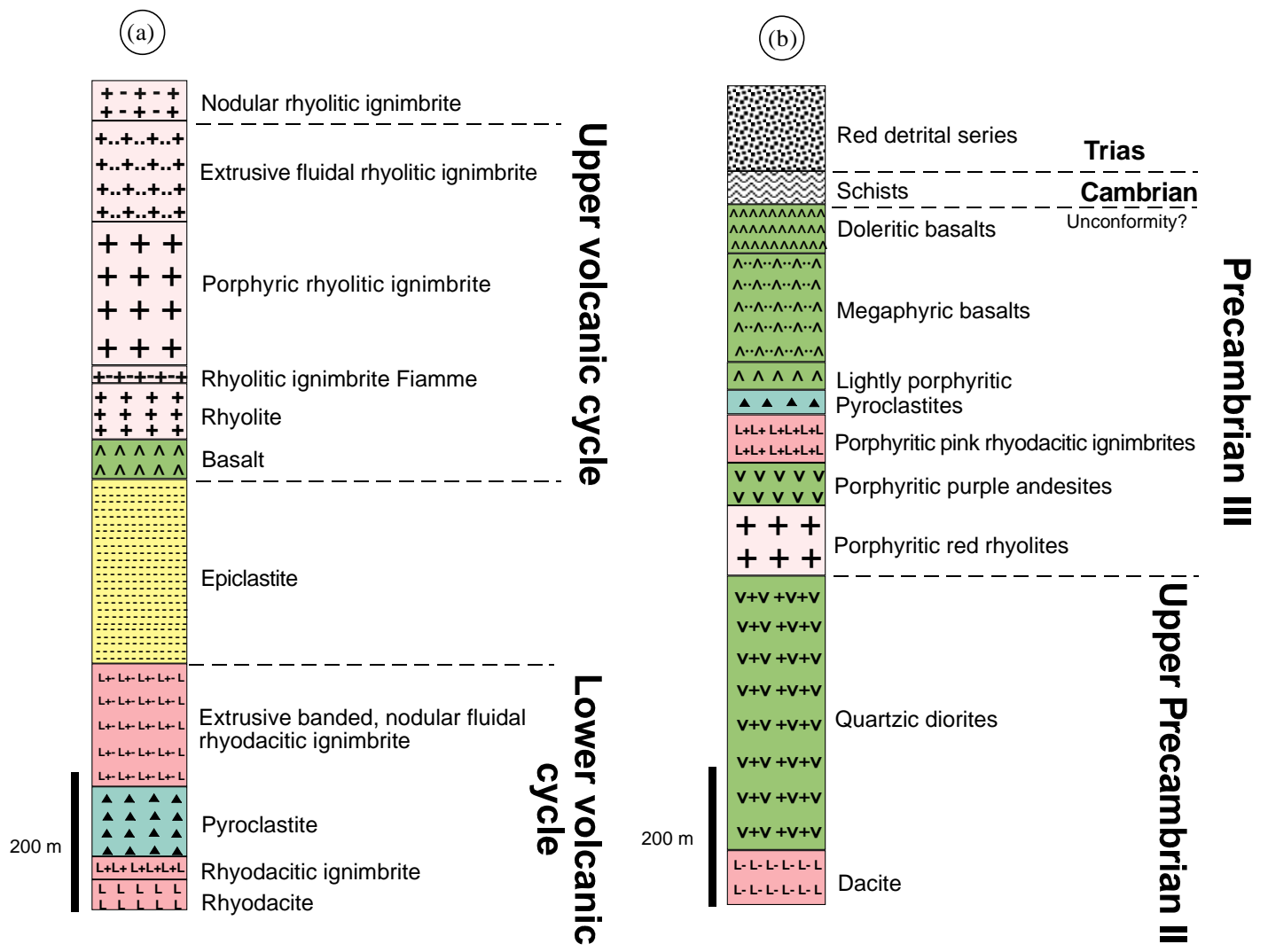

Figure 2. Lithostratigraphic column of the PIII formations of the High Atlas Old Massif: (a) Tircht; (b) Sidi Chamharouche.

(ii) Basalts of Tircht: These rocks were divided into two petrographic facies according to their microscopic aspect: the porphyritic microlitic facies and the vesicular porphyritic microlitic facies. The first facies represents the basic lava flow and displays a primary paragenesis including plagioclase (70\%; 0.25 - 2.75 mm), opacified olivine (7\%; $0.15-0.5 \mathrm{~mm}$ ) and opaque (5\%; $0.05-0.25 \mathrm{~mm})$. These components are included in a calcitized and hematitized very reduced mesostase $(4 \%)$.

The second facies constitutes the top of basaltic succession and is characterized by a mineralogical composition which, although it is similar to the former facies, is definitely less abundant (40\%). Moreover, the abundant vesicular mesostase (60\%) shows microlites of fine-plagioclase which are included in an entirely opacified background. The ferromagnesians (12\%), as the opaques (3\%), are included in feldspars (25\%) or scattered in the mesostase. The filling of vesicles $(10 \%-30 \%$; $0.5-2.5 \mathrm{~cm})$, is either of monomineral (calcite or quartz), or bimineral type (calcite and albite).

\section{Geochemical Affinity and Geodynamic Significance}

Six new complete chemical analyses (major, trace and REE elements) allow characterizing the studied igneous rocks (Table).

In the $\mathrm{Nb} / \mathrm{Y}-\mathrm{Zr} /\left(\mathrm{TiO}_{2} * 10\right.$ 000) diagram of [15], rocks of Tircht and Sidi Chamharouch are in the common field of the basalts and andesite (Figure 3 ).

Figure 4(a) shows chondrite-normalized REE patterns [16]. The Sidi Chamharouch basalt is weakly enriched in light rare earth elements (LREE) relative to the heavy rare earts elements (HREE) with normalized (La/Yb) $\mathrm{N}$ between 2.99 - 5.13. The REE patterns of the volcanic rocks from the Tircht are characterized by low fractionation with $(\mathrm{La} / \mathrm{Yb})_{\mathrm{N}}$ ranging between 2.38 - 2.63, similar to tholeiitic rocks. The positive anomalies in Eu may express the role of accumulation of plagioclases.

Plots of trace elements normalised to the average N-MORB are shown in Figure 4(b). The Tircht and Cham- 


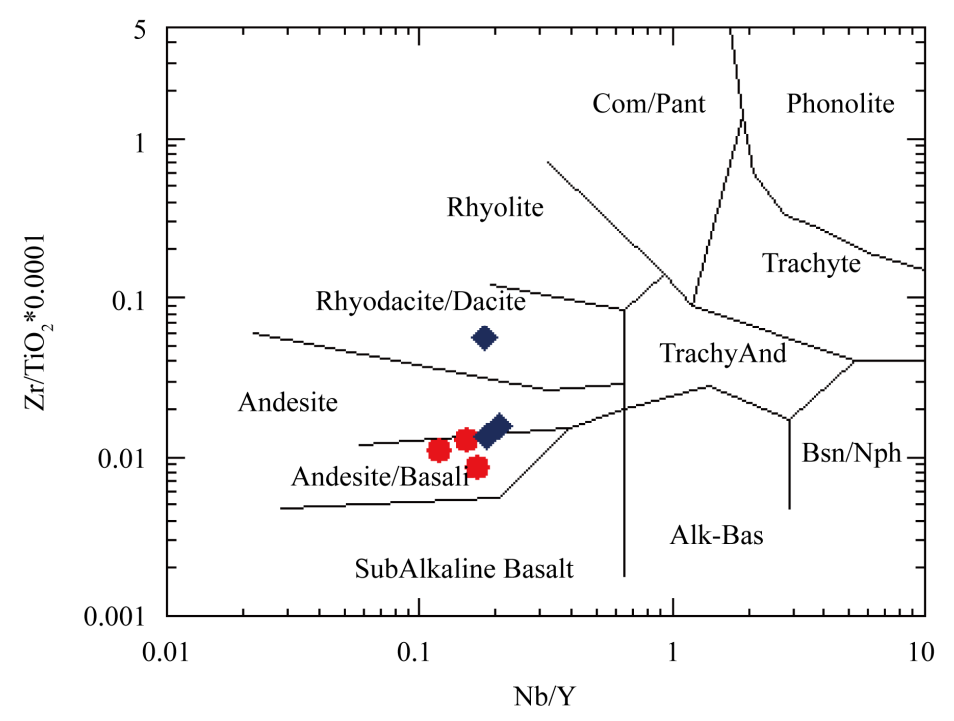

Figure 3. The Toubkal inlier volcanic rocks in the $\mathrm{Nb} / \mathrm{Y}-\mathrm{Zr} /\left(\mathrm{TiO}_{2} * 10000\right)$ diagram. Diamond: Sidi Chamharouch, Cercle: Tircht.

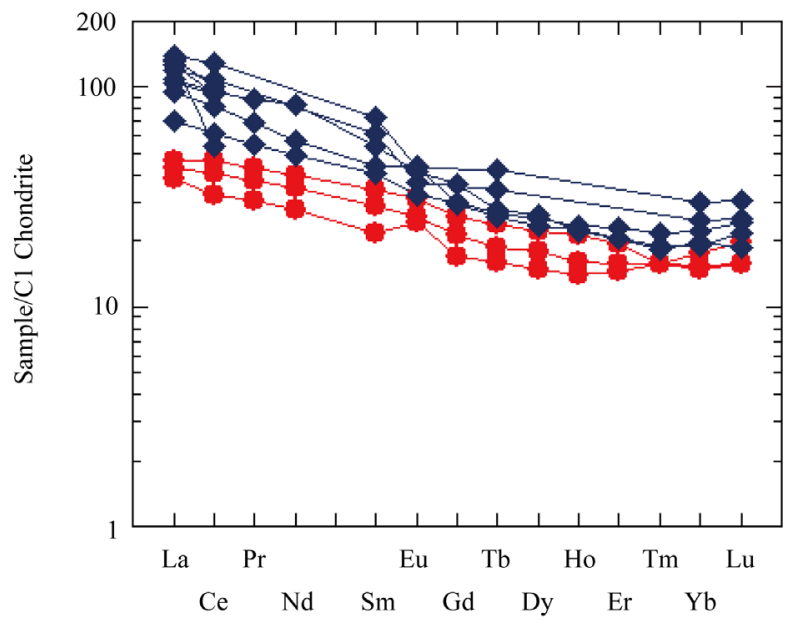

(a)

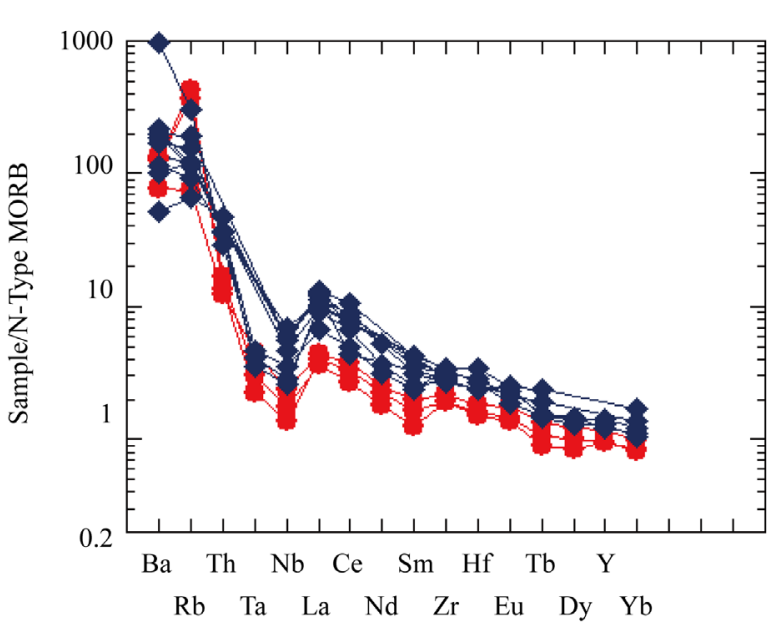

(b)

Figure 4. (a) Chondrite-normalized REE patterns and (b) Normalization diagram with respect to MORB for the Toubkal inlier volcanic rocks. Symbols as in Figure 3.

harouch rocks have high Th and HFSE (Nb, Ta, Zr and Hf) contents relative to MORB, a feature characteristic of tholeitic basalts [17]. Enriched LILE (Ba, Rb) relative to MORB are also present as expected for arc rocks, but this could partly be due to alteration. However, slight enrichment in the Tircht LREE may suggest that thehigh $\mathrm{Ba}$ and $\mathrm{Rb}$ relative abundances may be primary, typical of arc lavas rich in LILE and LREE. The spiderdiagram displays Nb-Ta thoughs similar to subduction magmas. This could be also the consequence of crustal contamination [18].

\section{Discussion and Conclusions}

Petrographical and geochemical studies lead to the following result, i.e. the Chamharouch and Tircht studied basaltic rocks are comparable to the tholeiitic rocks originated in the orogenic contexts. The $\mathrm{La} / \mathrm{Nb}$ ratios are relatively higher than 1.5 (1.7 - 5.2) suggesting a lithospheric mantle origin [15] [19] [20]. The high La/Ta ratios indicate a lithospheric source contaminated by the continental crust (17). The negative $\mathrm{Nb}$ anomaly confirms this assumption. 
A common and approved tool for the specification of tectonic settings of basaltic rocks is the $\mathrm{Zr} / \mathrm{Y}$-Zr diagram introduced by [17]. Most of the basalts rocks plot into the field of "within plate basalts" which is considered as a geochemical argument for rifting as the tectonic setting of the investigated rocks (Figure 5(a)).

Another commonly used diagram for discriminating tectonic setting is the $\mathrm{Th} / \mathrm{Yb}$ vs. Ta/Yb plot proposed by [21]. Figure 5(b) shows that all the investigated rocks are in the field of calc-alkaline orogenic rocks. This geochemical result allows the assumption that subduction active processes were indirectly responsible for the genesis of theses rocks.

In spite of the orogenic character of the studied rocks, it seems impossible to link this signature to a volcanic arc. Late Neoproterozoic paleogeography of the High Atlas (northern margin of the West African Craton), marked by the opening of a rift which never reached an oceanic stage, indicates a continental environment [6] [7] [22]. This allows ascribing the $\mathrm{Nb}$ anomaly, which can be encountered in extensional continental domains and the orogenic signature to partial melting of a metasomatized mantle by a continental component (source effect,

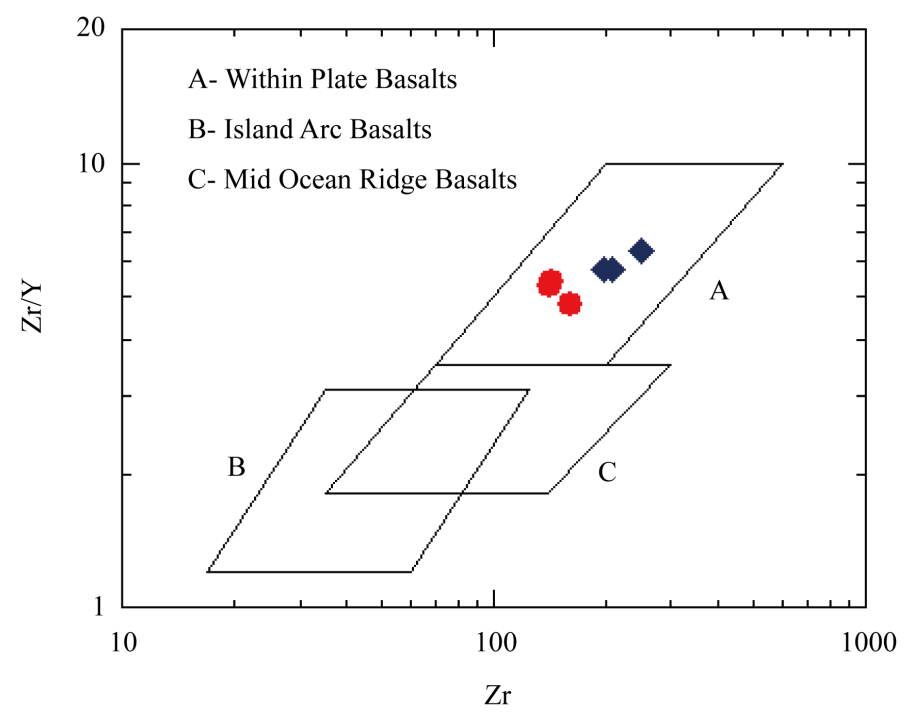

(a)

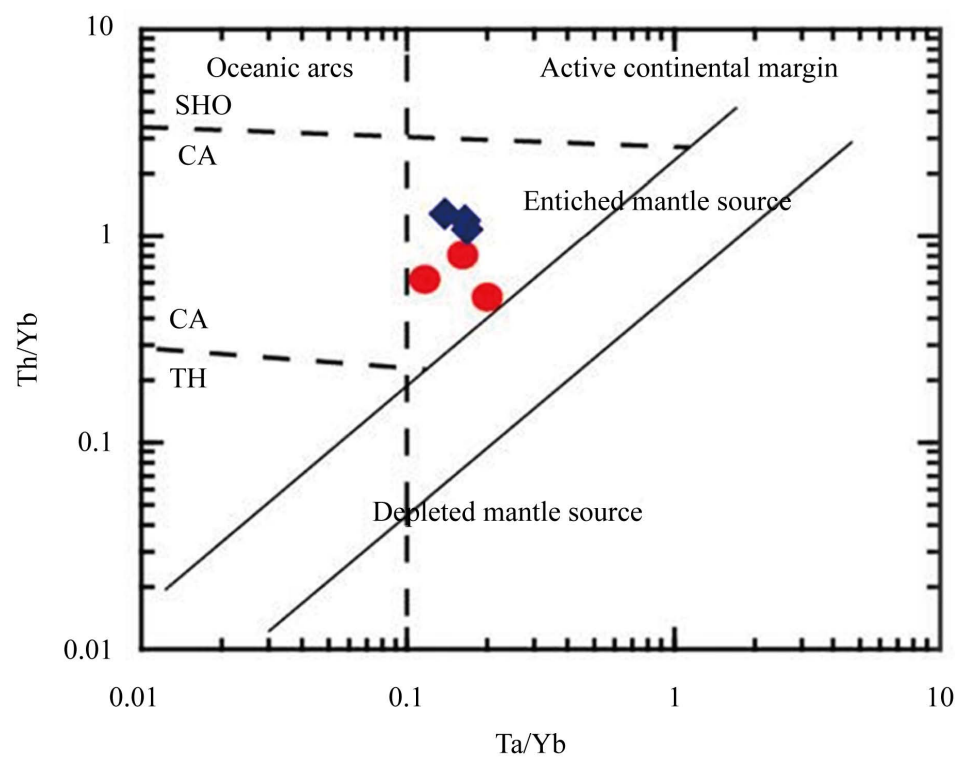

(b)

Figure 5. (a) Zr/Y-Zr tectonic setting diagram. Legend idem Figure 3; (b) $\mathrm{Th} / \mathrm{Yb}-\mathrm{Ta} / \mathrm{Yb}$ tectonic setting diagram. Legend idem Figure 3. 
[23]). The origin of this metasomatism may be of Pan-African age.

\section{References}

[1] Badra, L., Pouclet, A., Prost, A.E. and Touray, J.C. (1992) Mise en évidence d'une extension intra-plaque tardipanafricaine d'intérêt métallogénique dans le Haut Atlas occidental (Maroc). Comptes Rendus de l'Académie des Sciences, Series II, 314, 703-709.

[2] Ouazzani, H., Pouclet, A., Badra, L. and Prost, A. (2001) Le volcanisme d'arc du massif ancien de l'Ouest du HautAtlas occidental (Maroc), un témoin de la convergence de la branche occidentale de l'océan panafricain. Bulletin de la Société Géologique de France, 172, 587-602. http://dx.doi.org/10.2113/172.5.587

[3] Jouhari, A., El Archi, A., Aarab, M., El-Attari, A., Ennih, N. and Laduron, D. (2001) Géochimie et cadre géodynamique du volcanisme néoprotérozoïque terminal (Vendien) du Haut Atlas occidental, Maroc. Journal of African Earth Sciences, 32, 695-705. http://dx.doi.org/10.1016/S0899-5362(02)00049-0

[4] Sintubin, M., Nefly, M., Rijpens, J. and Zegbroek, B.V. (1997) Deformation History in Ourika Inlier, Implication for Fault Activity along the Tizi n’Test Fault Zone. Geology and Mijnbouw, 76, 187-195. http://dx.doi.org/10.1023/A:1003105710280

[5] Schaer, J.P. (1964) Volcanisme Cambrien dans le massif ancien du Haut Atlas occidental. Comptes Rendus Academic Sciences, 258, 2114-2117.

[6] Piqué, A. (2003) Evidence for an Important Extensional Event during the Latest Proterozoic and Earliest Paleozoic in Morocco. Comptes Rendus Geoscience, 335, 865-868. http://dx.doi.org/10.1016/j.crte.2003.08.005

[7] Piqué, A., Bouabdelli, M. and Darboux, J.R. (1995) Le rift cambrien du Maroc occidental. Comptes Rendus de l'Académie des Sciences, Series IIa, 320, 1017-1024.

[8] Campbell, I.H., Lesher, C.M., Coad, P., Franklin, J.M., Gorton, M.P. and Hurston, P.C. (1984) Rare Earth Element Mobility in Alteration Pipes below Massive Cu-Zn Sulfide Deposits. Chemical Geology, 45, 181-202. http://dx.doi.org/10.1016/0009-2541(84)90036-6

[9] Choubert, G. (1963) Histoire géologique de l’Anti-Atlas, de l'Archéen à l'aurore des temps primaires. Thèse Sc. Paris, Notes et Mém. Serv. Géol. Maroc, Rabat, 162.

[10] Nefly, M. (1998) Le massif cristallophyllien précambrien de l’Ourika (Haut-Atlas de Marrakech, Maroc): Exemple d'un dôme gneissique d'origine diapirique. Thèse d’Etat, Université Hassan II-Mohammédia, Fac. des Sci. de Ben M’Sik, Casablanca, 152 p.

[11] Plumb, K.A. (1991) New Precambrian Times Scale. Episodes, 14, 139-140.

[12] Zahour, G., Le Néoprotérozoïque terminal de la boutonnière de Toubkal (Haut-Atlas occidental) et de Siroua (AntiAtlas central) (2001) Un exemple de volcanisme intraplaque continental associé à un volcanisme calco-alcalin postcollisionnel. Thèse d'Etat, Université Hassan II-Mohammedia, Faculté des Sciences Ben M’Sik, Casablanca, 266 p.

[13] Baouch, S., Lahmam, M. and Pupin, J.P. (1990) Le magmatisme alcalin d’âge précambrien terminal d’Ouzellarh (Haut-Atlas occidental, Maroc): Origine et relation plutonisme-volcanisme d'après la typologie des zircons. Comptes Rendus Académie Sciences Paris 310, 1649-1655.

[14] Clauer, N. (1976) Géochimie isotopique du strontium des milieux sédimentaires. Application à la géochronologie de la couverture du craton Ouest-Africain. Thèse Sc. Strasbourg, Sc. Géol. Mem., Strasbourg, No. 45, 256 p.

[15] Floyd, P.A. and Winchester, J.A. (1975) Magma Type and Tectonic Setting Discrimination Using Immobile Elements. Earth and Planetary Science Letters, 27, 211-218. http://dx.doi.org/10.1016/0012-821X(75)90031-X

[16] Nakamura, N. (1974) Determination of REE, Ba, Fe, Mg, Na and K in Carbonaceous and Ordinary Chondrites. Geochimica et Cosmochimica Acta, 38, 757-775. http://dx.doi.org/10.1016/0016-7037(74)90149-5

[17] Pearce, J.A. (1983) Role of the Sub-Continental Lithosphere in Magma Genesis at Active Continental Margins. In: Hawkesworth, C.J. and Norry, M.J., Eds., Continental Basalts and Mantle Xenoliths, Shiva, Nantwich, 230-249.

[18] Dupuy, T. and Dostal, J. (1984) Trace Element of Some Continental Tholeiites. Earth and Planetary Science Letters, 67, 61-69. http://dx.doi.org/10.1016/0012-821X(84)90038-4

[19] Fitton, J.G., James, D., Kempton, P.D., Ormerod, D.S. and Leeman, W.P. (1988) The Role of Lithospheric Mantle in the Generation of Late Cenozoic Basic Magmas in the Western United States. Journal of Petrology, S1, 331-349. http://dx.doi.org/10.1093/petrology/special_volume.1.331

[20] Pearce, J.A. and Cann, J.R. (1973) Tectonic Setting of Basic Volcanic Rocks Determined Using Trace Element Analysis. Earth and Planetary Science Letters, 19, 290-300. http://dx.doi.org/10.1016/0012-821X(73)90129-5

[21] Müller, D., Rock, N.M.S. and Groves, D.I. (1992) Geo-Chemical Discrimination between Shoshonitic and Potassic Volcanic Rocks in Different Tectonic Settings: A Pilot Study. Mineralogy and Petrology, 46, 259-289. http://dx.doi.org/10.1007/BF01173568 
[22] Pouclet, A., Ouazzani, H. and Fekkak, A. (2008) The Cambrian Volcano-Sedimentary Formations of the Westernmost High Atlas (Morocco): Their Place in the Geodynamic Evolution of the West African Palaeo-Gondwana Northern Margin. Geological Society, London, Special Publications, 297, 303-327. http://dx.doi.org/10.1144/SP297.15

[23] Coish, R.A. and Sinton, C.W. (1992) Geochemistry of Mafic Dykes in the Adirondak Mountains: Implications for Late Proterozoic Continental Rifting. Contributions to Mineralogy and Petrology, 110, 500-514. http://dx.doi.org/10.1007/BF00344084

\section{Submit or recommend next manuscript to SCIRP and we will provide best service for you:}

Accepting pre-submission inquiries through Email, Facebook, LinkedIn, Twitter, etc. A wide selection of journals (inclusive of 9 subjects, more than 200 journals)

Providing 24-hour high-quality service

User-friendly online submission system

Fair and swift peer-review system

Efficient typesetting and proofreading procedure

Display of the result of downloads and visits, as well as the number of cited articles

Maximum dissemination of your research work

Submit your manuscript at: http://papersubmission.scirp.org/ 